\title{
Effects of the COVID-19 Pandemic on the Orthopedic Trauma Practice: Experiences From A University Hospital in Turkey
}

\author{
COVID-19 Pandemisinin Ortopedik Travma Pratiğine Etkileri: Türkiye’de Bir Üniversite Hastanesinin Deneyimi
}

'Eskisehir Osmangazi University Faculty of Medicine, Department of Orthopedics and Traumatology, Eskisehir, Turkey

${ }^{2}$ Eskisehir Osmangazi University Faculty of Medicine, Department of Biostatistics, Eskisehir, Turkey
Correspondence:

Mustafa KAVAK

Eskisehir Osmangazi University Faculty of Medicine, Department of Orthopedics and Traumatology, Eskisehir, Turkey

e-mail: kavak.m@gmail.com
${ }^{1}$ Mustafa Kavak, ${ }^{2}$ Muzaffer Bilgin, ${ }_{\mathbb{0}}^{1}$ Ulukan Inan

\section{Abstract}

After a new type of coronavirus in Wuhan, China was found to cause deadly pneumonia, the World Health Organization declared the disease caused by the viru a pandemic on March 11,2020. This situation led to the effectuation of some social restrictions that radically changed our daily lives in our country and across the world. This comprehensive change in social life also affected the daily practices in all branches of medicine as well as orthopedic trauma practice. The aim of this study was to evaluate the incidence, location, and treatment methods of the fractures seen in the pediatric and adult population during the pandemic period, and to investigate their differences with the pre-pandemic period. Our study was designed as a retrospective cohort study comparing the acute fractures admitted to our center during the pandemic period and the fractures that occurred before the pandemic. Patients who presented with a new fracture to our emergency ward or outpatient clinic between March 16,2020, and December 30, 2020, when social restrictions were in effect in our country were identified. Patients who applied to our center with a new fracture within the same date range in 2019 and 2018 se

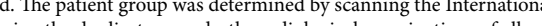
Classification of Diseases code and tients were evaluated by the researchers. The data regarding patients' age, gender, fracture location, treatment types, length of hospital stay, and in-hospital mortality
were recorded. The patients were divided into two groups: the pediatric group (16 years and younger) and the adult group (over 16 years). The total number of were recorded. The patients were divided into two groups: the pediatric group (16 years and younger) and the adult group (over 16 years). The total number of
fractures in the pandemic period was significantly less than in the non-pandemic period $(\mathrm{p}<0.001)$. Although the number of fractures decreased significantly in fractures in the pandemic period was significantly less than in the non-pandemic period $(\mathrm{p}<0.001)$. Although the number of fractures decreased significantly in
both groups $(\mathrm{p}<0.001)$, there was no significant difference between the pandemic and non-pandemic period data regarding the age groups $(\mathrm{p}=0.771)$. The most common fracture sites were the distal radius $(20 \%$ and $19.4 \%)$ and the ankle $(8,45 \%$ and $8.54 \%)$ in the non-pandemic period, while the distal radius $(21.5 \%)$ and the proximal femur $(10.8 \%)$ were the most involved sites in the pandemic period. The percentage of surgically treated fractures among all fractures was $49.6 \%$, $46.6 \%$, and $39.4 \%$ for 2018,2019 , and 2020, respectively. Although the prevalence of surgical treatments was lower in the pandemic period, the difference was not statistically significant $(\mathrm{p}=0.089)$. The mean length of hospital stay for the surgically treated fractures for all groups was $5.36 \pm 2.79,5.78 \pm 2.41$, and $4.10 \pm 1.62$ days for the years 2018,2019, and 2020 respectively. The decline in the length of stay during the pandemic period was found to be significant ( $\mathrm{p}<0.001)$. We experienced some cich We have seen how necessary and important previous experience can be in such extraordinary situations. The main motivation for us to carry out this study was to contribute to the knowledge in the literature. We observed a $26 \%$ decrease in the prevalence of fractures during the pandemic period. Although the indications for surgical treatment have not changed, we observed that the changes in the patient population and trauma mechanism also changed the treatment type. Keywords: COVID-19, epidemiology, fracture, pandemic, trauma.

\section{Özet}

Wuhan-Çin'deki yeni bir tür corono virüsün ölümcül pnömoniye neden olduğu tespit edildikten sonra Dünya Sağlı Örgütü 11 Mart 2020'de pandemi ilan etti. Bu durum tüm dünyada olduğu gibi ülkemizde de günlük hayatı kökten değiștiren bir takım sosyal kısıtlamalar uygulanmasına neden oldu.(1) Sosyal hayattaki bu kapsamlı değişiklik tüm tıp dallarındaki günlük pratikleri etkilediği gibi ortopedik travma pratiğini de etkiledi. Bu çalışmanın amacı, pandemi döneminde pediatrik ve erişkin popülasyonda görülen kırık insidansını, lokalizasyon dağılımlarını ve tedavilerini değerlendirmek ayrıca pandemi olmayan dönem ile farklılıkların araştırmaktır. Çalışmamız, COVID-19 pandemisi nedeniyle yaygın sosyal kısıtlamaların uygulandığı dönemde merkezimize başvuran akut kırıklar ile pandem öncesi döneme ait kırıkları karşılaştıran, retrospektif bir kohort çalışması olarak tasarlanmıștır. Ülkemizde sosyal kısıtlamaların uygulandığı 16 Mart 2020 ile 30 Aralık 2020 tarihleri arasında yeni kırık ile merkezimize acil servis ve ya poliklinik aracılığı ile başvuran hastalar hastane veri tabanı sistemi aracllığ ile belirlendi. Ayrıca 2019 ve 2018 yllında aynı tarih aralığında merkezimize yeni kırık ile başvuran hastalar belirlendi. Veri tabanı üzerinden ICD 10 kod ile ve ortopedik konsülta

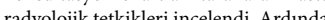
(2018 vele hastane içi mortalite verileri kayılt altına alınd. Hastalar pediatric grup ( 16 yaş ve altı) ile yetişkin grup ( 16 yaş ustü) olarak iki gruba ayrıld.. 2018,2019 ve 2020 yllna ait
veriler karssılastırıldı. Pandemic perioddaki toplam kırık sayısının nonpandemic döneme göre anlamlı derecede az olduğu görüldü. (p<0.001) Her ne kadar her iki veriler karşılaş̧ıııldı. Pandemic perioddaki toplam kırık sayısının nonpandemic döneme göre anlamlı derecede az olduğu görüldü. ( $<<0.001)$ Her ne kadar her iki
grupta kırık sayısı anlamlı derecede $(\mathrm{p}<0.001)$ azalsa da oransal olarak yaş dağılımına göre pandemic period ile non pandemic arasından anlamlı fark bulunmadı. $(\mathrm{p}=0.771)$ En sık görülen kırık lokalizasyonları pandemik dönemde distal radius $(21,5 \%)$ ve proksimal femur $(10,8 \%)$ iken non-pandemik dönemde 2018 ve 2019 yllarında distal radius $(20 \%$ ve $19,4 \%)$ ve ayak bileği $(8,45 \%$ ve $8,54 \%$ ) olduğu görüldü. Cerrahi tedavi edilen kırıkların toplam kırıklara oranı 2018,2019 ve 2020 yılları için sırasıyla 49,6\%, 46,6\% ve 39,4\% olduğu görüldü. Pandemik denemde cerrahi tedavi oranları düşük bulunsa da istatisliksel olarak anlamlı değildi. ( $\mathrm{p}=0.089$ ) Tüm gruplar için cerrahi olarak tedavi edilen kırıklarda hastanede yatış süreleri 2018,2019 ve 2020 ylları için sırasıyla ortalama $5.36 \pm 2.79,5.78 \pm 2.4 \mathrm{l}$ ve $4.10 \pm 1.62$ gündür. Pandemic periodda yatış sürelerindeki azalma anlamlı bulunmuştur. ( $\mathrm{p}<0.001)$ Pandeminin getirdiği olağanüstü şartlarda ortopedi günlük uygulamaları konusunda daha önce tecrübemiz olmaması nedeniyle bazı zorluklar ve kafa karısıklıkları yașadık. Fakat dünya genelinde ortopedik cerrahların konu ile ilgili deneyimlerini huzla paylasması sonucunda günlük uygulamalarmız kanita dayalı olarak netlesti. Bu gibi olağan diş durumlarda önceki tecrübelerin ne

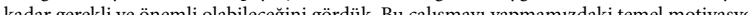
kadar gerekli ve önemli olabileceğini gördük. Bu çalışmayı yapmamızdaki temel motivasyon literaturdeki bu bilgi birikimine katkı sağlamaktı. Pandemi döneminde kırık sayııında $26 \%$ oranında azalma gözlemledik. Her ne kadar cerrahi tedavi endikasyonları değişmese de hasta popülasyonu ve travma mekanizmasındak
değişikliklerin tedavi tiplerini değiștirdiğini gözlemledik.

Anahtar Kelimeler: Varfarin; oral antikoagulasyon; kanama riski, kanama risk skorları 


\section{Introduction}

After a new type of coronavirus in Wuhan, China was found to cause deadly pneumonia, the World Health Organization declared the disease caused by the virus (COVID-19) a pandemic on March 11, 2020. This situation led to the effectuation of some social restrictions that radically changed our daily lives in our country and across the world (2). This comprehensive change in social life also affected the daily practices in all branches of medicine as well as orthopedic trauma practice (2).

The most common etiology of fractures are falls from height, simple falls in the elderly, after-school activities of children, sports injuries, and traffic accidents $(3,4)$. The incidence of fractures, as well as the etiology of fractures, has changed due to the extraordinary conditions faced during the pandemic period, such as quarantines, travel restrictions, distant education, and flexible and remote working practices (5-7). Similarly, we also observed changes in the type and number of fractures encountered in both adult and pediatric patients in our daily practices. In addition, the extraordinary conditions brought by the pandemic have revealed the necessity and importance of our previous orthopedic experiences in our daily practices. Studies on the incidence and prevalence of health services such as fracture surgery, which could not be interrupted or cancelled even during the pandemic period, will also be a reference in the management of health resources in possible similar future scenarios. Although orthopedics and trauma interventions do not appear at the forefront in the fight against COVID-19, they require good planning in terms of human resources and management since there are many orthopedic trauma cases that need to be dealt with urgently.

We believe that keeping records of the orthopedic trauma practices during the pandemic period in our center, where trauma patients are treated intensively, and comparing them to those of the pre-pandemic period sheds an important light on future studies. For this reason, the aim of this study was to evaluate the incidence, location, and treatment methods of the fractures seen in the pediatric and adult population during the pandemic period, and to investigate their differences with the pre-pandemic period.

\section{Patients and Methods}

This study was carried out with the approval of the local ethics committee. (no.29, date: Dec 30, 2020). Our study was designed as a retrospective cohort study comparing the acute fractures admitted to our center during the period of widespread social restrictions due to the COVID-19 pandemic and the fractures that occurred before the pandemic. Patients who presented with a new fracture to our emergency ward or outpatient clinic between March 16, 2020, and December 30, 2020, when social restrictions were in effect in our country, were identified. Patients who applied to our center with a new fracture within the same date range in 2019 and 2018 were also identified and compared to the former group of patients, who were considered to present during the "pandemic period'.

The patient group was determined by scanning the International Classification of Diseases, ICD-10 code, and orthopedic consultation charts on the database. After removing the duplicate records, the radiological examinations of all patients were evaluated by the researchers. Patients with conflicting data from ICD-10 diagnoses, orthopedic consultation charts, and radiological images were also excluded (total 17 patients). As a result, a total of 1,267 , 1,370 , and 963 fracture cases from the years 2018, 2019, and 2020 were included in the study. Then, data regarding patients' age, gender, fracture location, treatment types (conservative vs surgical), length of hospital stay (if treated surgically), and in-hospital mortality (if deceased) were recorded. The patients were divided into two groups: the pediatric group (16 years and younger) and the adult group (over 16 years).

\section{Statistical analysis}

The continuous data were expressed as mean \pm standard deviation and the categorical data as percentage (\%). The Shapiro-Wilk test was 
used to investigate the normality of the data. In comparing the normally distributed groups, independent samples t-test was used for comparing the cases with two groups, while one-way ANOVA was utilized when comparing the cases with three or more groups. As for the cases that were not normally distributed, the Mann-Whitney U test was used when comparing two groups and the Kruskal-Wallis $\mathrm{H}$ test when comparing three or more groups. Pearson's chi-square and Pearson's exact chi-square analyses were employed in analyzing the created cross tables. The IBM SPSS v.21.0 software (IBM Corp., Armonk, NY, USA) was used in all analyses. A p value less than 0.05 was accepted for statistical significance.

\section{Results}

The total number of fractures in the pandemic period was significantly less than in the nonpandemic period $(p<0.001)$. The number of fractures in the pediatric group by years and its ratio to the total number of fractures in the same year were $447(35.3 \%), 465$ (33.9\%), and $333(34.6 \%)$ for the years 2018,2019 , and 2020, respectively. As for the adult group, the number and percentage of the fractures by years were $820(64.7 \%), 905(66.1 \%)$, and $630(65.4 \%)$ for 2018, 2019, and 2020, respectively. Although the number of fractures decreased significantly in both groups $(\mathrm{p}<0.001)$, there was no significant difference between the pandemic and nonpandemic period data regarding the age groups $(p=0.771)$. The mean age of the patients based on the years investigated was $35.5 \pm 26.3,36.3 \pm 26.4$, and $36.9 \pm 27.0$ years for 2018, 2019, and 2020, respectively. There was no significant difference between the mean ages in the pandemic group and the nonpandemic group $(p=0.478)$. As for gender distributions, we found that $43.8 \%, 44 \%$, and $42.2 \%$ of the patients were females for the years 2018, 2019, and 2020, respectively $(p=0.639)$. The number of fractures, age distributions, and gender distributions by years are presented in Tables 1 and 2.

Table 1. Distribution of the number of fractures and the mean age data in the pediatric and adult groups by year.

Number of fractures

Mean age \pm SD

\begin{tabular}{ccccc}
\hline & $\begin{array}{c}\text { Pediatric group } \\
(\leq 16 \text { years old })\end{array}$ & $\begin{array}{c}\text { Adult group } \\
(>16 \text { years old })\end{array}$ & Total & \\
$\mathbf{2 0 1 8}$ & $447(35.3 \%)$ & $820(64.7 \%)$ & 1,267 & $35.5 \pm 26.3$ \\
$\mathbf{2 0 1 9}$ & $465(33.9 \%)$ & $905(66.1 \%)$ & 1,370 & $36.3 \pm 26.4$ \\
$\mathbf{2 0 2 0}$ & $333(34.6 \%)$ & $630(65.4 \%)$ & 963 & $36.9 \pm 27.0$ \\
$\mathbf{p}$ & $<0.001$ & $<0.001$ & $<0.001$ & 0.478 \\
\hline
\end{tabular}

Table 2. Distribution of the fractures based on gender, age groups, fracture sites, and length of hospital stays by year.

\begin{tabular}{|c|c|c|c|c|}
\hline & 2018 & 2019 & 2020 & p \\
\hline & $(\mathrm{n}=1,267)$ & $(\mathrm{n}=1,370)$ & $(\mathrm{n}=963)$ & \\
\hline \multicolumn{5}{|l|}{ Gender } \\
\hline Male & $712(56.2 \%)$ & $767(56.0 \%)$ & $557(57.8 \%)$ & 0.639 \\
\hline Female & $555(43.8 \%)$ & $603(44.0 \%)$ & $406(42.2 \%)$ & \\
\hline \multicolumn{5}{|l|}{ Age group } \\
\hline Pediatric & $447(35.3 \%)$ & $465(33.9 \%)$ & $333(34.6 \%)$ & 0.771 \\
\hline Adult & $820(64.7 \%)$ & $905(66.1 \%)$ & $630(65.4 \%)$ & \\
\hline \multicolumn{5}{|l|}{ Fracture location } \\
\hline Clavicle & $85(6.7 \%)$ & $89(6.5 \%)$ & $53(5.5 \%)$ & \\
\hline Scapula & $33(2.6 \%)$ & $40(2.9 \%)$ & $13(1.4 \%)$ & \\
\hline Proximal humerus & $72(5.7 \%)$ & $76(5.5 \%)$ & $52(5.4 \%)$ & \\
\hline Humerus shaft & $14(1.1 \%)$ & $16(1.2 \%)$ & $13(1.3 \%)$ & \\
\hline Distal humerus & $104(8.2 \%)$ & $116(8.5 \%)$ & $68(7.1 \%)$ & \\
\hline
\end{tabular}




\begin{tabular}{|c|c|c|c|c|}
\hline $\begin{array}{l}\text { Proximal radius- } \\
\text { ulna }\end{array}$ & $46(3.6 \%)$ & $49(3.6 \%)$ & $36(3.7 \%)$ & \multirow{18}{*}{0.419} \\
\hline Radius-ulnar shaft & $64(5.1 \%)$ & $67(4.9 \%)$ & $57(5.9 \%)$ & \\
\hline Distal radius-ulna & $253(20.0 \%)$ & $266(19.4 \%)$ & $207(21.5 \%)$ & \\
\hline Carpal & $10(0.8 \%)$ & $12(0.9 \%)$ & $6(0.6 \%)$ & \\
\hline Metacarpal & $26(2.1 \%)$ & $28(2.0 \%)$ & $18(1.9 \%)$ & \\
\hline Finger & $88(6.9 \%)$ & $100(7.3 \%)$ & $47(4.9 \%)$ & \\
\hline Pelvis & $41(3.2 \%)$ & $48(3.5 \%)$ & $19(2.0 \%)$ & \\
\hline Acetabulum & $11(0.9 \%)$ & $11(0.8 \%)$ & $4(0.4 \%)$ & \\
\hline Proximal femur & 90 (7.1\%) & $94(6.9 \%)$ & $104(10.8 \%)$ & \\
\hline Femoral shaft & $17(1.3 \%)$ & $17(1.2 \%)$ & $17(1.8 \%)$ & \\
\hline Distal femur & $14(1.1 \%)$ & $15(1.1 \%)$ & $15(1.6 \%)$ & \\
\hline Patella & $25(2.0 \%)$ & $28(2.0 \%)$ & $14(1.5 \%)$ & \\
\hline Proximal tibia & $30(2.4 \%)$ & $31(2.3 \%)$ & $21(2.2 \%)$ & \\
\hline Tibia shaft & $29(2.3 \%)$ & $31(2.3 \%)$ & $21(2.2 \%)$ & \\
\hline Ankle & $107(8.4 \%)$ & $117(8.5 \%)$ & $79(8.2 \%)$ & \\
\hline Calcaneus-talus & $33(2.6 \%)$ & $35(2.6 \%)$ & $26(2.7 \%)$ & \\
\hline Metatarsal & $57(4.5 \%)$ & $64(4.7 \%)$ & $51(5.3 \%)$ & \\
\hline Toe & $18(1.4 \%)$ & $20(1.5 \%)$ & $22(2.3 \%)$ & \\
\hline $\begin{array}{l}\text { Length of hospital } \\
\text { stay (days) }\end{array}$ & $5.36 \pm 2.79$ & $5.78 \pm 2.41$ & $4.10 \pm 1.62$ & $\mathrm{p}<0.001$ \\
\hline
\end{tabular}

Items with significant $p$ values are written in bold.

The most common fracture sites were the distal radius $(20 \%$ and $19.4 \%)$ and the ankle $(8,45 \%$ and $8.54 \%)$ in the non-pandemic period, while the distal radius $(21.5 \%)$ and the proximal femur $(10.8 \%)$ were the most involved sites in the pandemic period. Proximal femur fractures accounted for 7.1\% and $6.86 \%$ of all fractures in the nonpandemic and $10.8 \%$ of all fractures in the pandemic period. Pelvic fractures constituted $3.24 \%$ and $3.5 \%$ of all fractures in the nonpandemic period, whereas this rate was $1.97 \%$ in the pandemic period. Finger fractures were observed to have a prevalence of $6.95 \%$ and $7.3 \%$ in the non-pandemic period and $4.88 \%$ in the pandemic period, while toe fractures were encountered with prevalences of $1.42 \%$, $1.46 \%$, and $2.28 \%$ for the respective periods. The differences between fracture locations in the non-pandemic and pandemic periods were not statistically significant $(\mathrm{p}=0.419)$. The distribution of the fracture types by year is given in Table 2.

The percentage of surgically treated fractures among all fractures was $49.6 \%, 46.6 \%$, and $39.4 \%$ for 2018,2019 , and 2020 , respectively. Although the prevalence of surgical treatments was lower in the pandemic period, the difference was not statistically significant $(p=0.089)$. The distribution of the age groups, gender, and fracture locations according to treatment type and years are presented in Table 3. An individual evaluation of fracture locations demonstrated that the surgical treatment rates varied significantly in clavicular, proximal humeral, distal radial, proximal femoral, calcaneal-talar, and metatarsal fractures. While $38.8 \%$ of the clavicle fractures in 2018 and $37.1 \%$ in 2019 were treated surgically, surgical treatment was applied to only $5.7 \%$ of those in the pandemic period $(p<0.001)$. As for the proximal humerus fractures, $47.2 \%$ in $2018,44.7 \%$ in 2019 , and $15.4 \%$ in the pandemic period were treated surgically $(\mathrm{p}<0.001)$. The surgical treatment rates in distal radius fractures were $39.5 \%, 38 \%$, and $9.7 \%$ for the same periods $(\mathrm{p}<0.001)$. The surgical treatment rates in proximal femur fractures were $81.1 \%$ and $79.8 \%$ in the non-pandemic period, however, the rate increased to $96.2 \%$ in the pandemic period $(p=0.001)$. As for calcaneus-talus fractures, $45.5 \%$ and $45.7 \%$ of those in the non-pandemic period and $80.8 \%$ in the pandemic period received surgical treatment $(\mathrm{p}=0.009)$. The surgical treatment rates in metatarsal fractures were $33.3 \%$ and $31.3 \%$ in the non-pandemic period, whereas this rate decreased to $9.8 \%$ in the pandemic period $(\mathrm{p}=0.008)$. There was no significant difference regarding the rates of the treatment types of other fracture locations when compared based on years. The rates of the treatment types according to fracture locations and their distributions by years are shown in Table 4 . 
Table 3. Distribution of the treatment types based on gender, age groups, and fracture locations by year.

\begin{tabular}{|c|c|c|c|c|c|c|}
\hline & \multicolumn{2}{|c|}{2018} & \multicolumn{2}{|c|}{2019} & \multicolumn{2}{|c|}{2020} \\
\hline & Surgery & Conservative & Surgery & Conservative & Surgery & Conservative \\
\hline \multicolumn{7}{|l|}{ Gender } \\
\hline Male & $348(55.3 \%)$ & $364(57.1 \%)$ & $353(\% 55.2)$ & $414(56.6 \%)$ & $234(61.7 \%)$ & $323(55.3 \%)$ \\
\hline Female & $281(44.7 \%)$ & $274(42.9 \%)$ & $286(44.8 \%)$ & $317(43.4 \%)$ & $145(38.3 \%)$ & $261(44.7 \%)$ \\
\hline \multicolumn{7}{|l|}{ Age group } \\
\hline Pediatric & $178(28.3 \%)$ & $269(42.2 \%)$ & $174(27.2 \%)$ & $291(39.8 \%)$ & $81(21.4 \%)$ & $252(43.2 \%)$ \\
\hline Adult & $451(71.7 \%)$ & $369(57.8 \%)$ & $465(72.8 \%)$ & $440(60.2 \%)$ & $298(78.6 \%)$ & $332(56.8 \%)$ \\
\hline \multicolumn{7}{|l|}{ Fracture location } \\
\hline Clavicle & $33(5.2 \%)$ & $52(8.2 \%)$ & $33(5.2 \%)$ & $56(7.7 \%)$ & $3(0.8 \%)$ & $50(8.6 \%)$ \\
\hline Scapula & $5(0.8 \%)$ & $28(4.4 \%)$ & $6(0.9 \%)$ & $34(4.7 \%)$ & $0(0 \%)$ & $13(2.2 \%)$ \\
\hline Proximal humerus & $34(5.4 \%)$ & $38(6.0 \%)$ & $34(5.3 \%)$ & $42(5.7 \%)$ & $8(2.1 \%)$ & $44(7.5 \%)$ \\
\hline Humerus shaft & $6(1.0 \%)$ & $8(1.3 \%)$ & $6(0.9 \%)$ & $10(1.4 \%)$ & $9(2.4 \%)$ & $4(0.7 \%)$ \\
\hline Distal humerus & $55(8.7 \%)$ & $49(7.7 \%)$ & $55(8.6 \%)$ & $61(8.3 \%)$ & $34(9.0 \%)$ & $34(5.8 \%)$ \\
\hline Proximal radius-ulna & $20(3.2 \%)$ & $26(4.1 \%)$ & $20(3.1 \%)$ & $29(4.0 \%)$ & $10(2.6 \%)$ & $26(4.5 \%)$ \\
\hline Radius-ulnar shaft & $34(5.4 \%)$ & $30(4.7 \%)$ & $34(5.3 \%)$ & $33(4.5 \%)$ & $18(4.7 \%)$ & $39(6.7 \%)$ \\
\hline Distal radius-ulna & $100(15.9 \%)$ & $153(24.0 \%)$ & $101(15.8 \%)$ & $165(22.6 \%)$ & $20(5.3 \%)$ & $187(32.0 \%)$ \\
\hline Carpal & $5(0.8 \%)$ & $5(0.8 \%)$ & $5(0.8 \%)$ & $7(1.0 \%)$ & $1(0.3 \%)$ & $5(0.9 \%)$ \\
\hline Metacarpal & $14(2.2 \%)$ & $12(1.9 \%)$ & $14(2.2 \%)$ & $14(1.9 \%)$ & $6(1.6 \%)$ & $12(2.1 \%)$ \\
\hline Finger & $45(7.2 \%)$ & $43(6.7 \%)$ & $45(7.0 \%)$ & $55(7.5 \%)$ & $22(5.8 \%)$ & $25(4.3 \%)$ \\
\hline Pelvis & $16(2.5 \%)$ & $25(3.9 \%)$ & $16(2.5 \%)$ & $32(4.4 \%)$ & $4(1.1 \%)$ & $15(2.6 \%)$ \\
\hline Acetabulum & $6(1.0 \%)$ & $5(0.8 \%)$ & $6(0.9 \%)$ & $5(0.7 \%)$ & $3(0.8 \%)$ & $1(0.2 \%)$ \\
\hline Proximal femur & $73(11.6 \%)$ & $17(2.7 \%)$ & $75(11.7 \%)$ & $19(2.6 \%)$ & $100(26.4 \%)$ & $4(0.7 \%)$ \\
\hline Femoral shaft & $14(2.2 \%)$ & $3(0.5 \%)$ & $14(2.2 \%)$ & $3(0.4 \%)$ & $16(4.2 \%)$ & $1(0.2 \%)$ \\
\hline Distal femur & $13(2.1 \%)$ & $1(0.2 \%)$ & $14(2.2 \%)$ & $1(0.1 \%)$ & $12(3.2 \%)$ & $3(0.5 \%)$ \\
\hline Patella & $10(1.6 \%)$ & $15(2.4 \%)$ & $11(1.7 \%)$ & $17(2.3 \%)$ & $7(1.8 \%)$ & $7(1.2 \%)$ \\
\hline Proximal tibia & $22(3.5 \%)$ & $8(1.3 \%)$ & $22(3.4 \%)$ & $9(1.2 \%)$ & $17(4.5 \%)$ & $4(0.7 \%)$ \\
\hline Tibia shaft & $24(3.8 \%)$ & $5(0.8 \%)$ & $25(3.9 \%)$ & $6(0.8 \%)$ & $13(3.4 \%)$ & $8(1.4 \%)$ \\
\hline Ankle & $61(9.7 \%)$ & $46(7.2 \%)$ & $62(9.7 \%)$ & $55(7.5 \%)$ & $45(11.9 \%)$ & $34(5.8 \%)$ \\
\hline Calcaneus-talus & $15(2.4 \%)$ & $18(2.8 \%)$ & $16(2.5 \%)$ & $19(2.6 \%)$ & $21(5.5 \%)$ & $5(0.9 \%)$ \\
\hline Metatarsal & $19(3.0 \%)$ & $38(6.0 \%)$ & $20(3.1 \%)$ & $44(6.0 \%)$ & $5(1.3 \%)$ & $46(7.9 \%)$ \\
\hline Toe & $5(0.8 \%)$ & $13(2.0 \%)$ & $5(0.8 \%)$ & $15(2.1 \%)$ & $5(1.3 \%)$ & $17(2.9 \%)$ \\
\hline Total & $629(49.6 \%)$ & $638(50.4 \%)$ & $639(46.6 \%)$ & $731(53.4 \%)$ & $379(39.4 \%)$ & $584(60.6 \%)$ \\
\hline
\end{tabular}

Table 4. Distribution of the treatment types based on fracture locations by year.

\begin{tabular}{|c|c|c|c|c|c|c|c|}
\hline & \multicolumn{2}{|c|}{2018} & \multicolumn{2}{|c|}{2019} & \multicolumn{2}{|c|}{2020} & \multirow[t]{2}{*}{$\mathbf{p}$} \\
\hline & Surgery & Conservative & Surgery & Conservative & Surgery & Conservative & \\
\hline \multicolumn{8}{|l|}{ Fracture location } \\
\hline Clavicle & $33(38.8 \%)$ & $52(61.2 \%)$ & $33(37.1 \%)$ & $56(62.9 \%)$ & $3(5.7 \%)$ & $50(94.3 \%)$ & $<0.001$ \\
\hline Scapula & $5(15.2 \%)$ & $28(84.8 \%)$ & $6(15.0 \%)$ & $34(85.0 \%)$ & $0(0 \%)$ & $13(100 \%)$ & 0.325 \\
\hline Proximal humerus & $34(47.2 \%)$ & $38(52.8 \%)$ & $34(44.7 \%)$ & $42(55.3 \%)$ & $8(15.4 \%)$ & $44(84.6 \%)$ & $<0.001$ \\
\hline Humerus shaft & $6(42.9 \%)$ & $8(57.1 \%)$ & $6(37.5 \%)$ & $10(62.5 \%)$ & $9(69.2 \%)$ & $4(30.8 \%)$ & 0.203 \\
\hline Distal humerus & $55(52.9 \%)$ & $49(47.1 \%)$ & $55(47.4 \%)$ & $61(52.6 \%)$ & $34(50.0 \%)$ & $34(50.0 \%)$ & 0.720 \\
\hline $\begin{array}{l}\text { Proximal radius- } \\
\text { ulna }\end{array}$ & $20(43.5 \%)$ & $26(56.5 \%)$ & $20(40.8 \%)$ & $29(59.2 \%)$ & $10(27.8 \%)$ & $26(72.2 \%)$ & 0.310 \\
\hline Radius-ulnar shaft & $34(53.1 \%)$ & $30(46.9 \%)$ & $34(50.7 \%)$ & $33(49.3 \%)$ & $18(31.6 \%)$ & $39(68.4 \%)$ & 0.035 \\
\hline Distal radius-ulna & $100(39.5 \%)$ & $153(60.5 \%)$ & $101(38.0 \%)$ & $165(62.0 \%)$ & $20(9.7 \%)$ & $187(90.3 \%)$ & $<0.001$ \\
\hline Carpal & $5(50 \%)$ & $5(50 \%)$ & $5(41.7 \%)$ & $7(58.3 \%)$ & $1(16.7 \%)$ & $5(83.3 \%)$ & 0.407 \\
\hline Metacarpal & $14(53.8 \%)$ & $12(46.2 \%)$ & $14(50.0 \%)$ & $14(50.0 \%)$ & $6(33.3 \%)$ & $12(66.7 \%)$ & 0.380 \\
\hline Finger & $45(51.1 \%)$ & $43(48.9 \%)$ & $45(45.0 \%)$ & $55(55.0 \%)$ & $22(46.8 \%)$ & $25(53.2 \%)$ & 0.696 \\
\hline Pelvis & $16(39.0 \%)$ & $25(61.0 \%)$ & $16(33.3 \%)$ & $32(66.7 \%)$ & $4(21.1 \%)$ & $15(78.9 \%)$ & 0.389 \\
\hline Acetabulum & $6(54.5 \%)$ & $5(45.5 \%)$ & $6(54.5 \%)$ & $5(45.5 \%)$ & $3(75.0 \%)$ & $1(25.0 \%)$ & 0.748 \\
\hline Proximal femur & $73(81.1 \%)$ & $17(18.9 \%)$ & $75(79.8 \%)$ & $19(20.2 \%)$ & $100(96.2 \%)$ & $4(3.8 \%)$ & 0.001 \\
\hline Femoral shaft & $14(82.4 \%)$ & $3(17.6 \%)$ & $14(82.4 \%)$ & $3(17.6 \%)$ & $16(94.1 \%)$ & $1(5.9 \%)$ & 0.516 \\
\hline Distal femur & $13(92.9 \%)$ & $1(7.1 \%)$ & $14(93.3 \%)$ & $1(6.7 \%)$ & $12(80.0 \%)$ & $3(20.0 \%)$ & 0.430 \\
\hline Patella & $10(40.0 \%)$ & $15(60.0 \%)$ & $11(39.3 \%)$ & $17(60.7 \%)$ & $7(50.0 \%)$ & $7(50.0 \%)$ & 0.782 \\
\hline Proximal tibia & $22(73.3 \%)$ & $8(26.7 \%)$ & $22(71.0 \%)$ & $9(29.0 \%)$ & $17(81.0 \%)$ & $4(19.0 \%)$ & 0.711 \\
\hline Tibia shaft & $24(82.8 \%)$ & $5(17.2 \%)$ & $25(80.6 \%)$ & $6(19.4 \%)$ & $13(61.9 \%)$ & $8(38.1 \%)$ & 0.181 \\
\hline Ankle & $61(57.0 \%)$ & $46(43.0 \%)$ & $62(53.0 \%)$ & $55(47.0 \%)$ & $45(57.0 \%)$ & $34(43.0 \%)$ & 0.793 \\
\hline Calcaneus-talus & $15(45.5 \%)$ & $18(54.5 \%)$ & $16(45.7 \%)$ & $19(54.3 \%)$ & $21(80.8 \%)$ & $5(19.2 \%)$ & 0.009 \\
\hline Metatarsal & $19(33.3 \%)$ & $38(66.7 \%)$ & $20(31.3 \%)$ & $44(68.8 \%)$ & $5(9.8 \%)$ & $46(90.2 \%)$ & 0.008 \\
\hline Toe & $5(27.8 \%)$ & $13(72.2 \%)$ & $5(25.0 \%)$ & $15(75.0 \%)$ & $5(22.7 \%)$ & $17(77.3 \%)$ & 0.935 \\
\hline
\end{tabular}

Items with significant $p$ values are written in bold. 
The mean length of hospital stay for the surgically treated fractures for all groups was $5.36 \pm 2.79,5.78 \pm 2.41$, and $4.10 \pm 1.62$ days for the years 2018, 2019, and 2020, respectively. The decline in the length of stay during the pandemic period was found to be significant $(p<0.001)$. Lengths of hospital stays are shown in Table 2. All patients who were planned to receive surgical treatment during the pandemic period were screened with the polymerase chain reaction (PCR) test before hospitalization. In this period, 13 patients with positive results were treated in clinics with COVID-19 isolation measures, after consulting with infectious diseases specialists. Nine patients for whom surgical treatment could be delayed were operated on after COVID-19 treatments. Four patients aged 60 years and older who had hip fractures and tested positive for COVID-19 were operated on under maximum infection precaution measurements. Of them, one died due to respiratory failure on the sixth postoperative day.

\section{Discussion}

As a result of the decrease in people's mobility due to social isolation and quarantine practices effectuated during the pandemic period, a decrease in the incidence of fractures has been observed. These obligatory changes in the lifestyle of the society also changed the injury mechanisms, which in turn led to striking changes in fracture locations and types we encounter in clinical practice. The results of this study, in which we analyzed the changes observed in our daily practice, we noticed a $26 \%$ decrease in the incidence of fractures during the pandemic period compared to the pre-pandemic period. Other studies also reported similar decreases in the incidence of fractures during the pandemic period (5-14).

Turgut et al. (5) reported that the number of fractures decreased to one third during the pandemic period, while Bram et al. (6) reported a 2.5-fold decrease in pediatric fractures. Kalem et al. (7) reported that the incidence of fractures almost halved during the pandemic, and Hernigou et al. (8) stated that with the curfew, trauma rates in France decreased by $32 \%$ compared to previous years. In our study, we did not observe any difference between the pandemic and prepandemic period in terms of age distributions and mean age. Both Turgut et al. (5) and Bram et al. (6) showed that the mean age in the pediatric group decreased significantly during the pandemic period and associated this decline to the adolescent group's refrain from contact sports due to the closing of the schools and gyms and curfew measures. Although this inference seems logical, when the same scenario is considered for the adult group, it would be expected that the mean age in the adult group would increase after active adults' refrain from contact sports. In addition, the proportional increase in geriatric hip fractures should also cause an increase in the average age in the adult group. Ishii et al. reported that the mean age of the patients during the pandemic period was higher (14). We associate these differences with the patient population differences in the centers where the studies were conducted. Therefore, we believe that more accurate results can be achieved with meta-analyses.

We found that the most common fracture site was the distal radius, similar to the prepandemic period. Turgut et al. also reported in their study that the most common fractures during the pandemic and non-pandemic periods were distal radius fractures (5). We also found that the second most common fracture site was the ankle in the prepandemic period and the proximal femur in the pandemic period. Although the ratio of ankle fractures to all fractures did not change during the pandemic period, both the number and percentage of proximal femur fractures have increased. Kalem et al. examined the fracture mechanisms during the pandemic period and reported that $64.5 \%$ of the fractures were encountered at home and $73.9 \%$ were due to low-impact injuries (7). The increase in proximal femur fractures, which mostly occur as a result of domestic falls in geriatric patients, in comparison to the decrease in fracture incidence in the young population due to social restrictions during the pandemic period is an expected outcome. However, despite the decrease in the overall fracture incidence, the number of proximal femur fractures has increased. Contrary to our study, there are studies in the literature 
reporting no change in the number of adult hip fractures during the pandemic period (7-10). On the other hand, Ishii et al. (14) reported an increase in the number of hip fractures during the pandemic period, similar to our study. In our country, during the pandemic period, social restrictions were implemented for a longer period of time to people aged 65 and over, who were considered a high-risk group. We believe that this practice increases immobilization in the geriatric population, and therefore may lead to an increase in osteoporotic fractures.

The overall rate of surgical treatment did not change compared to the pre-pandemic period. However, when we evaluated the fracture location individually, we observed that the surgical treatment rates changed in some fracture types. The rate of surgical treatment of clavicle fractures has decreased during the pandemic period. When we investigated the reason behind this, we noticed that the majority of the clavicle fractures during the pandemic period were in the pediatric group. The conservative treatment of the majority of pediatric clavicle fractures explains this decrease in the surgical treatment rates during the pandemic period. Similarly, we observed that the surgical treatment rates in proximal humeral fractures also decreased during the pandemic period. We believe that this is because most of the proximal humerus fractures in the pandemic period have occurred as a result of falling at home in geriatric patients and that conservative treatment was more prominent in geriatric proximal humerus fractures. We observed that the changes in the patient population were the reason for the decrease in the rate of surgical treatment of distal radius fractures during the pandemic period. We have seen that the majority of distal radius fractures in the pandemic period have occurred in pediatric and geriatric patients after a low-energy trauma such as falling indoors. The surgical treatment rates of proximal femur fractures increased during the pandemic period. While almost all of the proximal femur fractures in the pandemic period were in geriatric patients, we saw that the prevalence of these fractures was increased in pediatric patients in the prepandemic period. We believe that this difference explains the increase in the surgical treatment rate. In the evaluation of the increase in the surgical treatment rate of calcaneus-talus fractures during the pandemic period, we observed no difference among the patients in terms of age and fracture mechanism. The effect of fracture type and patient comorbidities on the treatment plan may have caused this situation. We have seen that the reason for the decrease in the surgical treatment rate of metatarsal fractures was that most of the fractures during the pandemic period were caused by in-home low-energy traumas. Although surgical treatment indications have not changed, we observed that the changes in the patient population and trauma mechanism also changed the treatment type. On the other hand, Turgut et al. (5) reported that the rate of surgical treatment in the pediatric age group doubled during the pandemic period. The authors asserted that the reason for this might be that the families of the patients with minor traumas avoided presenting to the hospital during the pandemic period and that other centers referred fractures that required surgery to the authors' institution. Similarly, Kalem et al. reported that although there was a decrease in the number of patients admitted to the hospital due to trauma, there was an increase in the number of patients who underwent surgical treatment (7). In our study, we did not find any difference in the overall surgical treatment rates compared to the pre-pandemic period. However, we saw some differences in fracture location and associated this with the differences in the patient population and fracture types. During the pandemic period, different practices were carried out in the provision of health services in different cities and centers, according to local needs. We believe that these different practices are the reason for the differences between the studies.

In our study, there was a significant decrease in the length of hospital stays of the patients treated surgically during the pandemic period compared to the pre-pandemic period. Similarly, Turgut et al. reported a significant decrease in the duration of hospitalization (5), contrary to Kalem et al. who stated that there was no change in the duration of hospitalization during the pandemic period 
compared to the previous period (7). We believe that the main reason for the decrease in the length of hospital stays is the risk of transmission of COVID-19, which is a common concern of patients and surgeons.

Although we conducted this study in a trauma center with a high volume of patients, this may not reflect the general trend since it is a single-center study. Another important limitation to our study was its retrospective design. On the other hand, in our study, fractures were evaluated within a period of approximately nine months. Considering the shorter periods in similar studies, this long period can be considered an advantage of our study. Another strength of our study was the elimination of possible errors owing to the examination of the radiological images of each patient, as well as using the ICD-10 codes during the identification of fracture patients.

In conclusion, we experienced some difficulties and confusion due to our lack of previous experience in orthopedic daily practices under the extraordinary conditions brought by the pandemic. However, as orthopedic surgeons around the world quickly shared their experiences on the subject, our daily practices became clear based on evidence. We have seen how necessary and important previous experience can be in such extraordinary situations. The main motivation for us to carry out this study was to contribute to the knowledge in the literature. We observed a $26 \%$ decrease in the prevalence of fractures during the pandemic period. Although the indications for surgical treatment have not changed, we observed that the changes in the patient population and trauma mechanism also changed the treatment type. Further multicenter and national studies are required to shed light on orthopedic practices in extraordinary situations such as a pandemic which we might probably encounter in the future

\section{REFERENCES}

1. Özdin S, Bayrak Özdin Ş. Levels and predictors of anxiety, depression and health anxiety during COVID-19 pandemic in Turkish society: The importance of gender. Int J Soc Psychiatry. 2020;66:504-11.

2. Neher RA, Dyrdak R, Druelle V, et al. Potential impact of seasonal forcing on a SARS-CoV-2 pandemic. Swiss Med Wkly. 2020;150:w20224.

3. Landin LA. Epidemiology of children's fractures. J Pediatr Orthop B. 1997;6:79-83.

4. Court-Brown CM, Caesar B. Epidemiology of adult fractures: A review. Injury. 2006;37:6917.

5. Turgut A, Arlı H, Altundağ Ü, et al. Effect of COVID-19 pandemic on the fracture demographics: Data from a tertiary care hospital in Turkey. Acta Orthop Traumatol Turc. 2020;54:355-63.

6. Bram JT, Johnson MA, Magee LC, et al. Where Have All the Fractures Gone? The Epidemiology of Pediatric Fractures During the COVID-19 Pandemic. J Pediatr Orthop. 2020;40:373-9.

7. Kalem M, Kocaoğlu H, Merter A, et al. Effects of COVID-19 pandemic curfew on orthopedic trauma in a tertiary care hospital in Turkey. Acta Orthop Traumatol Turc. 2021;55:191-5.
8. Hernigou J, Morel X, Callewier A, et al. Staying home during "COVID-19" decreased fractures, but trauma did not quarantine in one hundred and twelve adults and twenty eight children and the "tsunami of recommendations" could not lockdown twelve elective operations. Int Orthop. 2020;44:147380.

9. Pichard R, Kopel L, Lejeune Q, et al. Impact of the COronaVIrus Disease 2019 lockdown on hand and upper limb emergencies: experience of a referred university trauma hand centre in Paris, France. Int Orthop. 2020;44:1497-501.

10. Nuñez JH, Sallent A, Lakhani K, et al. Impact of the COVID-19 Pandemic on an Emergency Traumatology Service: Experience at a Tertiary Trauma Centre in Spain. Injury. 2020;51:1414-8.

11. Muñoz Vives JM, Jornet-Gibert M, CámaraCabrera J, et al. Mortality Rates of Patients with Proximal Femoral Fracture in a Worldwide Pandemic: Preliminary Results of the Spanish HIP-COVID Observational Study. J Bone Joint Surg Am. 2020;102:e69.

12. Kumar Jain V, Lal H, Kumar Patralekh M, Vaishya R. Fracture management during COVID-19 pandemic: A systematic review. $J$ Clin Orthop Trauma. 2020;11:S431-S441. 
13. Segarra B, Ballesteros Heras N, Viadel Ortiz $\mathrm{M}$, et al. Are Hospitals Safe? A Prospective Study on SARS-CoV-2 Prevalence and Outcome on Surgical Fracture Patients: A Closer Look at Hip Fracture Patients. J Orthop Trauma. 2020;34:e371-e376.

14. Ishii K, Kurozumi T, Suzuki T, et al. Impact of the COVID-19 pandemic on a trauma center of a university hospital in Japan [published online ahead of print, 2020 Dec 29]. J Orthop Sci. 2020;S0949-2658(20)30360

@Copyright 2022 by Osmangazi Tıp Dergisi - Available online at tip.ogu.edu.tr @Telif Hakkı 2022 ESOGÜ Tıp Fakültesi - Makale metnine dergipark.org.tr/otd web sayfasından ulaşılabilir. 